\title{
THE VARIATIONS OF THE SODIUM SPACE AND THE TOTAL EXCHANGEABLE SODIUM DURING PREGNANCY ${ }^{1}$
}

\author{
By MARY JANE GRAY AND ALBERT A. PLENTL \\ (From the Department of Obstetrics and Gynecology, Columbia University, College of Physicians \\ and Surgeons, and The Presbyterian Hospital, New York, N. Y.)
}

(Submitted for publication September 14, 1953; accepted November 25, 1953)

Excessive sodium retention has been implicated as a primary or contributing factor in the etiology of pre-eclampsia and evidence to this effect is said to be well substantiated. An increase in serum sodium concentrations during such abnormal pregnancies has never been demonstrated and it is, therefore, concluded that sodium is stored by expansion of the extra-cellular space or incorporated in selected cell systems.

Careful sodium balance studies (1-5) on limited numbers of normal pregnant patients at isolated gestational periods have also pointed to a persistent retention of sodium, which would lead to the suspicion that there exists a quantitative rather than qualitative difference between normal and preeclamptic patients. A definition of the expected variations in the sodium content of normal pregnant patients would be an essential base line for further investigations on the sodium metabolism in abnormal pregnancies.

The present report relates to a study of the total exchangeable sodium and the sodium space by the isotope dilution method. It was undertaken in an effort to define the limits of normal variations for uncomplicated pregnancies.

\section{METHODS ${ }^{2}$}

Because of the potential hazard involved in the use of radioactive materials in pregnant women, the number of determinations performed during this study was sharply limited. The dosage used was 30 microcuries of $\mathrm{Na}^{24}$ per determination per patient, at minimum intervals of four weeks not exceeding six such determinations per antepartum course. On the third or fourth postpartum day and again four weeks after delivery, the determinations

1 This investigation was supported by a Research Grant from the National Institutes of Health, Department of Health, Education and Welfare.

2 The authors are indebted to Dr. E. Quimby of the Department of Radiologic Research for her unfailing cooperation, advice and assistance during all phases of the investigations here presented. of sodium space and total exchangeable sodium were repeated.

After a control sample of blood was drawn from the patient, an infusion of 5 per cent dextrose in water was started. An accurately known volume of the tracer solution containing approximately 30 microcuries of $\mathrm{Na}^{2 \mathrm{x}}$ was allowed to flow into the infusion tubing fom a $25 \mathrm{ml}$. analytic burette by a method previously described (6). Blood samples were then drawn at 3,5, and 24-hour intervals. The urine was collected over the same 24-hour period.

The unused portion of the solution remaining in the burette was collected and set aside for comparison and determination of the total dose administered. In order to bring the test solution within the appropriate range of the analyzing instrument, a dilution of the specimens to 1:200 was found to be most satisfactory. One-half $\mathrm{ml}$. portions of this diluted tracer solution, $0.5 \mathrm{ml}$. of the 3 , 5 , and 24-hour serum samples and $2 \mathrm{ml}$. aliquots of pooled urine were pipetted into planchets in triplicate and dried under an infra-red heat lamp. Because of the low dosage administered, the counting was performed by means of a Nuclear Q-gas counter. The number of counts averaged over 300 per minute and was in excess of ten times the background. All counts were corrected for background and radioactive decay as well as serum absorption. The sodium space was calculated from average values obtained on 3 and 5-hour sera and a knowledge of the total number of counts administered by the familiar formula:

Sodium Space in $\mathrm{ml}$.

$$
=\frac{(\text { count } / \mathrm{sec} . / \mathrm{ml} \text {. of test sol.) (ml. injected) }}{\text { counts } / \mathrm{sec} . / \mathrm{ml} \text {. of serum }}
$$

For the calculation of the 24-hour sodium space, the total radioactivity of the 24-hour urine was subtracted from the number of counts injected. The 24-hour sodium space multiplied by the concentration of sodium in the serum (mEq. per $1000 \mathrm{ml}$.) gave the "total exchangeable sodium" in milliequivalents. The sodium content of the 24-hour serum was estimated by the flame-photometric technique.

\section{CLINICAL MATERIAL}

Ten primigravidae were chosen for this study on the basis of a normal history, physical examination, and routine laboratory tests. An effort was made to use volunteers who registered during the first trimester, in order to obtain experimental data over as long a period as pos- 
sible and to provide a base line for future, anticipated changes. One of these patients developed signs and symptoms of mild pre-eclampsia during her third trimester, and underwent Cesarean section at term because of cephalo-pelvic disproportion. Two patients had short episodes of hyperemesis gravidarum during the first trimester, and one was hospitalized near term because of nausea and vomiting. The six remaining patients had entirely uncomplicated antepartum courses. All infants were normal, and none of the mothers had any complication during the puerperium.

\section{RESULTS}

Most of the data obtained on these patients are reproduced in Table I. All patients had normal weight gains according to the range set forth by Chesley (7). Although there is an absolute gain in sodium space from the beginning of pregnancy until term, the values show little variation when expressed as per cent of body weight. Only the pre-eclamptic patient, B. D., showed a significant increase in sodium space expressed as per cent of body weight, during the third trimester.

The absolute values for the total exchangeable sodium show a similar, though not exactly parallel, increase during pregnancy, but when these figures are expressed as milliequivalents per kilogram they remain essentially unchanged.

TABLE I

The absolute and relative values of sodium space and total exchangeable sodium and their changes during normal and pathologic pregnancies

\begin{tabular}{|c|c|c|c|c|c|c|c|c|}
\hline Patient & $\begin{array}{l}\text { Week } \\
\text { of ges- } \\
\text { tation }\end{array}$ & Weight & $\begin{array}{c}\text { Sodium } \\
\text { space }\end{array}$ & $\begin{array}{l}\text { Sodium } \\
\text { space }\end{array}$ & $\begin{array}{l}\text { Total } \\
\text { exchange- } \\
\text { able } \\
\text { sodium }\end{array}$ & $\begin{array}{c}\text { Total } \\
\text { exchange- } \\
\text { able } \\
\text { sodium }\end{array}$ & $\begin{array}{c}\text { Total } \\
\text { exchange- } \\
\text { able } \\
\text { sodium }\end{array}$ & $\begin{array}{c}\text { Sodium } \\
\text { space }\end{array}$ \\
\hline B. W. & $\begin{array}{l}10 \\
16 \\
22 \\
28 \\
33 \\
38 \\
2 \text { days p.p. } \\
1 \text { mo. p.p. }\end{array}$ & $\begin{array}{l}K g . \\
80.0 \\
77.4 \\
86.4 \\
85.5 \\
87.7 \\
91.7 \\
87.1 \\
86.1\end{array}$ & $\begin{array}{c}L . \\
18.5 \\
18.5 \\
21.8 \\
19.9 \\
20.8 \\
20.6 \\
21.1 \\
21.0\end{array}$ & $\begin{array}{c}\text { \% body wt. } \\
23.1 \\
23.9 \\
25.2 \\
23.3 \\
23.7 \\
22.5 \\
24.2 \\
24.4\end{array}$ & $\begin{array}{l}m E q . \\
2606 \\
3553 \\
3470 \\
3311 \\
3449 \\
3146 \\
3052 \\
3555\end{array}$ & $\begin{array}{c}m E q . / K_{g} . \\
32.6 \\
45.9 \\
40.2 \\
38.8 \\
39.3 \\
33.3 \\
35.1 \\
41.3\end{array}$ & $\begin{array}{c}m E q . / m .{ }^{2} \\
1316 \\
1813 \\
1700 \\
1631 \\
1674 \\
1491 \\
1489 \\
1743\end{array}$ & $\begin{array}{r}L . / m . .^{2} \\
9.34 \\
9.42 \\
10.66 \\
9.80 \\
10.10 \\
9.76 \\
10.29 \\
10.29\end{array}$ \\
\hline J. B. & $\begin{array}{l}10 \\
16 \\
22 \\
27 \\
32 \\
38 \\
3 \text { days p.p. } \\
1 \text { mo. p.p. }\end{array}$ & $\begin{array}{l}65.5 \\
64.3 \\
66.4 \\
68.2 \\
70.9 \\
72.1 \\
65.1 \\
62.7\end{array}$ & $\begin{array}{l}16.1 \\
16.2 \\
16.3 \\
17.0 \\
16.2 \\
18.0 \\
14.1 \\
15.9\end{array}$ & $\begin{array}{l}24.7 \\
25.2 \\
24.6 \\
24.9 \\
22.9 \\
25.0 \\
21.7 \\
25.5\end{array}$ & $\begin{array}{l}2489 \\
2507 \\
2340 \\
2760 \\
2934 \\
3063 \\
2232 \\
2599\end{array}$ & $\begin{array}{l}38.0 \\
39.0 \\
35.3 \\
40.5 \\
41.4 \\
42.5 \\
34.6 \\
41.4\end{array}$ & $\begin{array}{l}1439 \\
1458 \\
1336 \\
1564 \\
1621 \\
1683 \\
1290 \\
1529\end{array}$ & $\begin{array}{l}9.34 \\
9.42 \\
9.31 \\
9.60 \\
8.90 \\
9.89 \\
8.15 \\
9.35\end{array}$ \\
\hline R. C. & $\begin{array}{l}10 \\
16 \\
22 \\
30 \\
38 \\
3 \text { days p.p. } \\
1 \text { mo. p.p. }\end{array}$ & $\begin{array}{l}68.6 \\
73.6 \\
78.2 \\
82.3 \\
83.4 \\
76.8 \\
73.6\end{array}$ & $\begin{array}{l}15.9 \\
17.3 \\
18.8 \\
19.4 \\
19.8 \\
18.4 \\
16.0\end{array}$ & $\begin{array}{l}23.2 \\
23.5 \\
24.0 \\
24.8 \\
25.3 \\
23.9 \\
21.7\end{array}$ & $\begin{array}{l}2355 \\
2510 \\
3164 \\
2959 \\
2859 \\
2874 \\
2283\end{array}$ & $\begin{array}{l}34.3 \\
34.0 \\
40.5 \\
36.0 \\
34.3 \\
37.4 \\
31.0\end{array}$ & $\begin{array}{l}1346 \\
1233 \\
1674 \\
1533 \\
1474 \\
1545 \\
1248\end{array}$ & $\begin{array}{r}9.09 \\
9.44 \\
9.92 \\
10.03 \\
10.23 \\
9.87 \\
8.74\end{array}$ \\
\hline S. S. & $\begin{array}{r}12 \\
18 \\
24 \\
30 \\
35 \\
* 39 \\
4 \text { days p.p. } \\
1 \text { mo. p.p. }\end{array}$ & $\begin{array}{l}\mathbf{5 2 . 3} \\
\mathbf{5 6 . 1} \\
\mathbf{5 8 . 4} \\
60.2 \\
61.1 \\
\mathbf{5 9 . 8} \\
\mathbf{5 5 . 2} \\
\mathbf{5 4 . 0}\end{array}$ & $\begin{array}{l}13.6 \\
13.0 \\
14.4 \\
13.1 \\
13.8 \\
15.8 \\
12.9 \\
12.5\end{array}$ & $\begin{array}{l}26.0 \\
23.2 \\
24.7 \\
21.8 \\
22.5 \\
26.4 \\
23.4 \\
23.2\end{array}$ & $\begin{array}{l}2286 \\
2008 \\
2526 \\
2227 \\
2213 \\
2085 \\
1971 \\
1928\end{array}$ & $\begin{array}{l}43.7 \\
35.8 \\
43.3 \\
37.0 \\
36.2 \\
34.9 \\
35.7 \\
35.7\end{array}$ & $\begin{array}{l}1504 \\
1287 \\
1588 \\
1392 \\
1374 \\
1303 \\
1272 \\
1252\end{array}$ & $\begin{array}{l}8.95 \\
8.33 \\
9.08 \\
8.22 \\
8.54 \\
9.88 \\
8.32 \\
8.12\end{array}$ \\
\hline G. S. & $\begin{array}{c}16 \\
21 \\
26 \\
30 \\
3 \text { days p.p. } \\
1 \text { mo. p.p. }\end{array}$ & $\begin{array}{l}53.2 \\
55.5 \\
57.8 \\
57.1 \\
56.1 \\
54.3\end{array}$ & $\begin{array}{l}14.9 \\
16.4 \\
15.2 \\
15.1 \\
12.6 \\
14.4\end{array}$ & $\begin{array}{l}28.1 \\
29.5 \\
26.2 \\
26.4 \\
22.4 \\
26.5\end{array}$ & $\begin{array}{l}2142 \\
2442 \\
2586 \\
2663 \\
2355 \\
2647\end{array}$ & $\begin{array}{l}40.3 \\
44.1 \\
44.7 \\
46.7 \\
42.0 \\
48.7\end{array}$ & $\begin{array}{l}1400 \\
1536 \\
1626 \\
1696 \\
1510 \\
1713\end{array}$ & $\begin{array}{r}9.74 \\
10.55 \\
9.53 \\
9.59 \\
8.08 \\
9.35\end{array}$ \\
\hline
\end{tabular}

* Patient hospitalized because of nausea and vomiting. 
TABLE I-Continued

\begin{tabular}{|c|c|c|c|c|c|c|c|c|}
\hline Patient & $\begin{array}{l}\text { Week } \\
\text { of ges- } \\
\text { tation }\end{array}$ & Weight & $\begin{array}{l}\text { Sodium } \\
\text { space }\end{array}$ & $\begin{array}{l}\text { Sodium } \\
\text { space }\end{array}$ & $\begin{array}{c}\text { Total } \\
\text { exchange- } \\
\text { able } \\
\text { sodium }\end{array}$ & $\begin{array}{l}\text { Total } \\
\text { exchange- } \\
\text { able } \\
\text { sodium }\end{array}$ & $\begin{array}{c}\text { Total } \\
\text { exchange- } \\
\text { able } \\
\text { sodium }\end{array}$ & $\begin{array}{l}\text { Sodium } \\
\text { space }\end{array}$ \\
\hline J. W. & $\begin{array}{l}13.0 \\
19 \\
25 \\
31 \\
37 \\
3 \text { days p.p. } \\
1 \text { mo. p.p. }\end{array}$ & $\begin{array}{l}K_{8} . \\
57.2 \\
56.7 \\
55.5 \\
60.0 \\
61.7 \\
54.8 \\
55.0\end{array}$ & $\begin{array}{c}L . \\
12.4 \\
14.5 \\
14.5 \\
15.9 \\
16.6 \\
16.6 \\
14.4\end{array}$ & $\begin{array}{c}\text { \% body wot. } \\
21.7 \\
25.6 \\
26.2 \\
26.4 \\
26.9 \\
27.6 \\
26.1\end{array}$ & $\begin{array}{l}m E q . \\
2077 \\
2257 \\
2278 \\
2969 \\
2588 \\
2502 \\
2208\end{array}$ & $\begin{array}{c}m E q . / K g . \\
36.3 \\
39.8 \\
41.1 \\
49.5 \\
41.9 \\
45.7 \\
40.1\end{array}$ & $\begin{array}{c}m E q . / m . .^{2} \\
1340 \\
1456 \\
1488 \\
1856 \\
1598 \\
1625 \\
1434\end{array}$ & $\begin{array}{r}. / m .2 \\
8.00 \\
9.35 \\
9.48 \\
9.91 \\
10.25 \\
10.78 \\
9.32\end{array}$ \\
\hline T. M. & $\begin{array}{c}11 \\
* 15 \\
21 \\
27 \\
32 \\
37 \\
3 \text { days p.p. } \\
1 \text { mo. p.p. }\end{array}$ & $\begin{array}{l}64.1 \\
59.7 \\
61.8 \\
64.3 \\
65.6 \\
68.2 \\
65.3 \\
59.6\end{array}$ & $\begin{array}{l}13.7 \\
13.7 \\
17.0 \\
17.1 \\
18.3 \\
18.2 \\
15.3 \\
12.6\end{array}$ & $\begin{array}{l}21.4 \\
22.9 \\
27.5 \\
26.5 \\
27.7 \\
26.7 \\
23.3 \\
21.6\end{array}$ & $\begin{array}{l}2317 \\
1905 \\
2442 \\
2960 \\
2905 \\
2923 \\
2321 \\
1990\end{array}$ & $\begin{array}{l}38.0 \\
31.9 \\
39.9 \\
46.9 \\
44.3 \\
42.9 \\
35.5 \\
33.4\end{array}$ & $\begin{array}{l}1371 \\
1161 \\
1490 \\
1751 \\
1689 \\
1680 \\
1349 \\
1170\end{array}$ & $\begin{array}{r}8.10 \\
8.35 \\
10.30 \\
10.09 \\
10.55 \\
10.46 \\
8.89 \\
7.68\end{array}$ \\
\hline J.P. & $\begin{array}{c}11 \\
17 \\
23 \\
27 \\
32 \\
37 \\
4 \text { days p.p. } \\
1 \text { mo. p.p. }\end{array}$ & $\begin{array}{l}55.9 \\
57.1 \\
59.3 \\
60.5 \\
61.5 \\
61.1 \\
56.6 \\
56.9\end{array}$ & $\begin{array}{l}12.7 \\
13.2 \\
14.6 \\
14.1 \\
14.4 \\
15.6 \\
13.4 \\
12.2\end{array}$ & $\begin{array}{l}22.7 \\
23.2 \\
24.5 \\
23.3 \\
23.3 \\
25.5 \\
23.6 \\
21.4\end{array}$ & $\begin{array}{l}2057 \\
2232 \\
2615 \\
2485 \\
2286 \\
2407 \\
1948 \\
2323\end{array}$ & $\begin{array}{l}36.8 \\
39.1 \\
44.1 \\
41.1 \\
37.2 \\
39.4 \\
34.4 \\
40.8\end{array}$ & $\begin{array}{l}1327 \\
1431 \\
1655 \\
1563 \\
1429 \\
1504 \\
1249 \\
1489\end{array}$ & $\begin{array}{l}8.19 \\
8.47 \\
9.22 \\
8.87 \\
8.97 \\
9.75 \\
8.56 \\
7.82\end{array}$ \\
\hline J. L. & $\begin{array}{l}13 \\
18 \\
25 \\
30 \\
34 \\
38 \\
4 \text { days p.p. } \\
1 \text { mo. p.p. }\end{array}$ & $\begin{array}{l}59.1 \\
62.5 \\
66.3 \\
69.6 \\
73.5 \\
75.2 \\
70.2 \\
66.4\end{array}$ & $\begin{array}{l}14.4 \\
15.6 \\
14.0 \\
14.8 \\
14.2 \\
17.7 \\
14.0 \\
13.2\end{array}$ & $\begin{array}{l}24.4 \\
24.9 \\
21.1 \\
21.3 \\
19.3 \\
23.5 \\
19.9 \\
19.9\end{array}$ & $\begin{array}{l}2271 \\
2431 \\
2240 \\
2530 \\
2604 \\
2876 \\
2182 \\
1956\end{array}$ & $\begin{array}{l}38.4 \\
38.9 \\
33.3 \\
36.4 \\
35.4 \\
38.2 \\
31.1 \\
31.6\end{array}$ & $\begin{array}{l}1446 \\
1473 \\
1358 \\
1479 \\
1505 \\
1643 \\
1291 \\
1185\end{array}$ & $\begin{array}{r}9.17 \\
9.66 \\
8.48 \\
8.76 \\
8.21 \\
10.11 \\
8.28 \\
8.00\end{array}$ \\
\hline B. D. & $\begin{array}{r}23 \\
27 \\
31 \\
35 \\
+39 \\
\text { 3.days p.p. } \\
\text { 1 mo. p.p. }\end{array}$ & $\begin{array}{l}67.3 \\
68.0 \\
70.3 \\
70.9 \\
70.9 \\
61.4 \\
60.2\end{array}$ & $\begin{array}{l}18.3 \\
20.2 \\
22.4 \\
23.8 \\
15.0 \\
-\end{array}$ & $\begin{array}{l}27.2 \\
29.6 \\
31.8 \\
33.6 \\
24.5 \\
-\end{array}$ & $\begin{array}{l}2443 \\
3196 \\
3147 \\
3942 \\
3699 \\
3131 \\
2762\end{array}$ & $\begin{array}{l}36.3 \\
47.0 \\
44.7 \\
55.6 \\
52.2 \\
51.0 \\
45.9\end{array}$ & $\begin{array}{l}1420 \\
1847 \\
1798 \\
2240 \\
2102 \\
1694 \\
1694\end{array}$ & $\begin{array}{c}10.64 \\
11.68 \\
12.77 \\
\overline{13.52} \\
9.09 \\
-\end{array}$ \\
\hline
\end{tabular}

† Patient hospitalized because of signs and symptoms of pre-eclampsia.

The values for sodium space and total exchangeable sodium are also expressed per square meter of body surface, a terminology used by other authors (8); this manner of presentation is said to be particularly advantageous in investigations on the physiology of pregnancy.

Table II summarizes the data by trimester, their sum, and the puerperium but excludes the data obtained on the pre-eclamptic patient. The sodium space throughout pregnancy averaged 24.4 per cent of body weight, with a range of 19.3 to 29.5 per cent. The total exchangeable sodium averaged $39.3 \mathrm{mEq}$. per $\mathrm{Kg}$. with a range from 31.9 to 49.5 $\mathrm{mEq}$. per $\mathrm{Kg}$. The corresponding values for the pre-eclamptic patient were within normal limits during the second trimester but showed a significant rise during the early part of the third trimester, preceding the time at which clinical evidence for pre-eclampsia developed. The gain in total exchangeable sodium during pregnancy and its loss during the puerperium for the six entirely normal patients are presented in Table III. These patients gained an average of $510 \mathrm{mEq}$. of sodium during an average of 26 weeks of pregnancy and lost an average of $440 \mathrm{mEq}$. of sodium during the puerperium.

The hyperemetic patients (T. M., B. W., and S. S.) and the patient who eventually developed 
TABLE II

The average values for the total, exchangeable sodium and the sodium space of six normal patients arranged according to trimesters and the postpartum period

\begin{tabular}{lcc}
\hline Period & $\begin{array}{c}\text { Total } \\
\text { exchange- } \\
\text { able } \\
\text { sodium }\end{array}$ & $\begin{array}{c}\text { Sodium } \\
\text { space as } \\
\text { \% of body } \\
\text { weight }\end{array}$ \\
\hline 1st trimester & $\begin{array}{c}m E q . / K_{\mathrm{g}} \\
37.3\end{array}$ & $\begin{array}{c}23.4 \\
(32.6-43.7)\end{array}$ \\
2nd trimester & 39.9 & $(21.4-26.0)$ \\
3rd trimester & $(31.9-46.0)$ & 24.9 \\
All trimesters & 39.2 & $(21.1-29.5)$ \\
Postpartum & $(33.3-49.5)$ & $(19.3-27.7)$ \\
& 39.3 & 24.4 \\
& $(31.9-49.5)$ & $(19.3-29.5)$ \\
& 37.5 & 23.3 \\
& $(31.0-48.7)$ & $(19.9-27.6)$
\end{tabular}

pre-eclampsia (B. D.) were not included in Table III. Preceding and during episodes of hyperemesis these patients lost appreciable amounts of sodium as shown by a drop in the total exchangeable sodium which, after treatment, returned to normal limits.

\section{COMMENT}

The demonstration by Moore (9) that it is possible to calculate the total amount of an element in the body provides a means of studying metabolic processes. The application of this principle to elec-

TABLE III

Calculation of the average gain and loss of the total exchangeable sodium during the ante- and postpartum period based upon the data obtained on six entirely normal patients

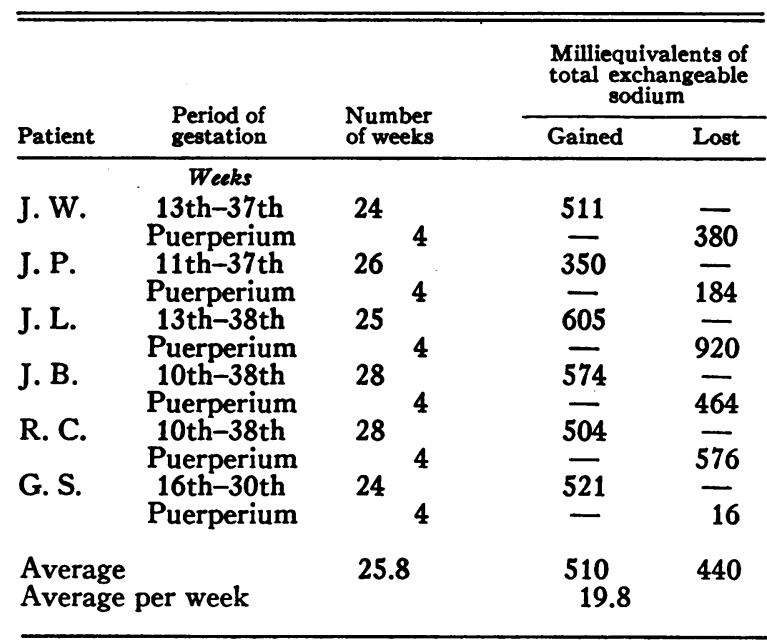

trolyte metabolism can yield indirect information on the intake and output of these elements, and thus serve as a metabolic balance study.

The values obtained for the total exchangeable sodium over the whole period of normal gestation are roughly of the same magnitude per unit body mass as those obtained by other authors for nonpregnant, normal, female subjects. To date a total of only 16 such determinations were carried out on female subjects as reported by Forbes and Perley (10), Miller and Wilson (11), and other investigators (12). The results do not differ materially from normal male subjects if they are expressed in milliequivalents of sodium per kilogram of body weight (10-13). All of these values except one, reported by Forbes and Perley (54.1 $\mathrm{mEq}$. per Kg.), are within a range of $2 \sigma$ of any set of values here reported.

Comparing the changes in weight recorded on the 10 patients here investigated, all fall well within the expected range (7), whether the weight one month postpartum is taken as a norm or the patient's stated pre-pregnancy weight is used as a point of reference. Even the pre-eclamptic patient gained weight only within these limits which is to be expected because of the reported lack of correlation of weight gain and incidence of toxemia. In addition to the net gain these weight changes also showed the expected progression except for the three subjects who were hospitalized because of excessive vomiting.

The loss of water, although not directly determined, is presumably reflected in the loss of weight observed on the three patients in question (T. M., B. W., and S. S.). Because of inadequate nutrition, these patients were in a negative sodium balance, hence the total exchangeable sodium would be expected to decline. A substantial fall in the absolute and relative values for the total exchangeable sodium substantiates this deduction. The loss of sodium is proportionately less than the loss of water and chloride and a decline in extracellular anions should then cause a similar decline in ca. tions if a state of compensated acidosis is to be maintained. A relatively small drop in the serum sodium concentration, if reflected in the whole extracellular fluid, should cause an apparent, but not real, expansion of the fluid volume of distribution of sodium. This affords an explanation for the 
striking increase in sodium space, not only in its relative, but also in its absolute values in the face of a pronounced fall in total exchangeable sodium.

In contrast to the positive rate of gain in weight which reaches its maximum value at term, the rate of retention of sodium is inconsistent. Maximal sodium retention may occur any time during the second trimester, but the net gain, regardless of fluctuations, appears to be reasonably constant. The six entirely normal patients gained an average of $510 \mathrm{mEq}$. of exchangeable sodium with an average gain of about $20 \mathrm{mEq}$. per week.

This retention of sodium is considerably less than predicted by other authors. Freyberg, Reekie, and Folsome (5) reported the lowest value for the weekly retention of sodium during the latter part of pregnancy, namely $1.61 \mathrm{Gm}$. (70 mEq.). Thompson and Pommerenke (1) and Taylor, Warner, and Welsh (2) reported an almost identical value of $3.08 \mathrm{Gm}$. (134.0 mEq.) gain per week, a value which agrees with the data reported by Hummel, Steinberger, Hunscher, and Macy (3), who thought that the gain amounted to $3.92 \mathrm{Gm}$. (170 mEq.) per week. Coons, Coons, and Schiefelbusch (4) concluded that the average weekly gain was $8.81 \mathrm{Gm}$. (383 mEq.).

The lowest of these values (5) was determined over the last 70 days of the period of gestation. This corresponds to a daily retention of $0.231 \mathrm{Gm}$. of sodium or a total of $16.3 \mathrm{Gm}$. for these 70 days of investigation. The rate of gain of sodium according to Taylor, Warner, and Welsh (2) near the end of pregnancy amounted to $0.440 \mathrm{Gm}$. per day or $26.4 \mathrm{Gm}$. in two months. This would mean that a normal patient would increase her total sodium content by an additional 45 per cent during the last two months of pregnancy, and, if the figures of Coons, Coons, and Schiefelbusch (4) are accepted, she would have to double her sodium content during that time.

While most of these studies were carried out during the latter part of pregnancy, one group of investigators (Thompson and Pommerenke [1]) also reported a value of $0.440 \mathrm{Gm}$. per day for the fourth month of gestation. If this figure were accepted, it would imply that the sodium content of an average patient would more than double during the last two trimesters.

The data here reported indicate that only 12.0 $\mathrm{Gm}$. of sodium ( $510 \mathrm{mEq}$.) were retained during the last two trimesters. About one-half to twothirds of this amount can be accounted for in the products of gestation, and the remainder is to be sought in the expanded maternal blood volume. The concentration of sodium in the amniotic fluid is nearly equal to that of plasma, and, since the average volume of the amniotic fluid in term pregnancies is about $850 \mathrm{ml}$. (14), this would contain about $110 \mathrm{mEq}$. of sodium. The sodium space of term infants according to Perley, Forbes, and Pennoyer (15) is about 35.2 per cent of body weight, which, for a plasma sodium concentration of $135 \mathrm{mEq}$., would correspond to a total exchangeable sodium of $47.5 \mathrm{mEq}$. per $\mathrm{Kg}$. A term baby weighing $3200 \mathrm{Gm}$. would, therefore, contain about $152 \mathrm{mEq}$. of exchangeable sodium. If during pregnancy the maternal plasma had expanded by $1500 \mathrm{ml}$., this would, under conditions of unchanged sodium concentration, account for the remainder.

The fact that an almost equivalent amount of sodium is lost during the delivery and the puerperium, further demonstrates the correctness of these calculations and experimental data.

A possible explanation for the discrepancy between these data and those of others may be sought in the fact that in the present study only the exchangeable sodium has been determined while the classical balance studies consider the net gain in the sum of exchangeable and permanent sodium. One would have to assume that enormous amounts of sodium are stored in bone in a non-exchangeable form, and direct evidence to this effect does not exist.

Numerous attempts have been made to determine the extracellular fluid space and its changes during pregnancy. The distribution of thiocyanate, bromide, radio-sodium, and inulin have been used for this purpose. By far the largest number of determinations based on the distribution of thiocyanate have been reported by Chesley and Chesley $(16,17)$, but these results cannot easily be compared with those obtained by others. A value of 28.2 per cent of body weight reported by Freis and Kenny (18) is in good agreement with the findings of Caton, Roby, Reid, and Gibson (8). The application of the bromide dilution method gave similar results in the hands of Friedman, Goodfriend, Berlin, and Goldstein (19). So far only two reports on the use of radio-sodium have appeared, 
and both indicate that there is no appreciable difference between the sodium space and the thiocyanate space. Nineteen such analyses by Cox and Chalmers (20), gave an average of 27.9 per cent of body weight during the last trimester, and Lambiotte-Escoffier, Moore, and Taylor (21), found a sodium space of 26 and 29.6 per cent of body weight on two normal pregnant subjects.

Only the data of Caton, Roby, Reid, and Gibson (8) include the earlier phases of pregnancy. In order to compare results here presented with those obtained by others, it would be necessary to limit this comparison to the third trimester, where the values here reported give an average of 24.3 with a standard deviation of 2.2. One can, therefore, assume that the sodium space of 95.5 per cent of all normal patients falls within a range of 19.9 to 28.6 per cent of body weight. This represents a much narrower range than that reported by Cox and Chalmers (20), which may well be due to the uniformity of parity and age of our subjects.

In the calculation of average values, the data obtained on patient D. B. were excluded because of clinical signs and symptoms of pre-eclampsia. The obvious increase of the total exchangeable sodium in this patient beyond the established limits for normal pregnant patients suggests that sodium is retained, but does not permit a differentiation between an expansion of the volume of distribution due to an increase in intracellular sodium or an expansion of the extracellular fluid space (21).

\section{SUM MARY}

Ten primigravidae of comparable age were followed throughout their pregnancies by frequent determination of sodium space and total body sodium. Two of these patients had short periods of hyperemesis gravidarum, one was hospitalized near term because of vomiting and one developed signs and symptoms of mild pre-eclampsia.

The relative values for sodium space and total exchangeable sodium did not change appreciably for each of the normal patients during the period of observation. An average value of 24.4 per cent (range 19.3 to 29.5 ) of body weight was obtained for the sodium space, and the total exchangeable sodium was found to be 39.3 (range 31.9 to 49.5 ) milliequivalents per kilogram of body weight.
The total exchangeable sodium of the patient who eventually developed pre-eclampsia remained within normal limits during the second trimester, but exceeded the statistical limits in the early part of the third trimester, at which time no clinical evidence for pre-eclampsia existed.

The six normal patients showed an average absolute gain in total exchangeable sodium of 20 milliequivalents per week, or a total of 500 milliequivalents during the second and third trimester. This increment in exchangeable sodium could be accounted for in the products of gestation and the expanded maternal blood volume. No evidence for retention of exchangeable sodium was obtained.

\section{REFERENCES}

1. Thompson, H. E., Jr., and Pommerenke, W. T., Electrolyte and nitrogen metabolism in pregnancy. J. Nutrition, 1939, 17; 383.

2. Taylor, H. C., Jr., Warner, R. C., and Welsh, C. A., The relationship of the estrogens and other placental hormones to sodium and potassium balance at the end of pregnancy and in the puerperium. Am. J. Obst. \& Gynec., 1939, 38, 748.

3. Hummel, F. C., Steinberger, H. R., Hunscher, H. A., and Macy, I. G., Metabolism of women during the reproductive cycle. VII. Utilization of inorganic elements (a continuous case study of a multipara). J. Nutrition, 1936, 11, 235.

4. Coons, C. M., Coons, R. R., and Schiefelbusch, A. T., The acid base balance of the minerals retained during human pregnancy. J. Biol. Chem., 1934, 104, 757.

5. Freyberg, R. H., Reekie, R. D., and Folsome, C., A study of water sodium, and energy exchange during the latter part of pregnancy. Am. J. Obst. \& Gynec., 1938, 36, 200 .

6. Plentl, A. A., and Gelfand, M. M., A modification of the dye-dilution method for serial estimations of plasma volume. Surg., Gynec. \& Obst., In press.

7. Chesley, L. C., Weight changes and water balance in normal and toxic pregnancy. Am. J. Obst. \& Gynec., 1944, 48, 565.

8. Caton, W. L., Roby, C. C., Reid, D. E., and Gibson, J. G., 2nd, Plasma volume and extravascular fluid volume during pregnancy and the puerperium. Am. J. Obst. \& Gynec., 1949, 57, 471.

9. Moore, F. D., Determination of total body water and solids with isotopes. Science, 1946, 104, 157.

10. Forbes, G. B., and Perley, A., Estimation of total body sodium by isotopic dilution. I. Studies on young adults. J. Clin. Invest., 1951, 30, 558.

11. Miller, H., and Wilson, G. M., The measurement of exchangeable sodium in man using the isotope ${ }^{x} \mathrm{Na}$. Clin. Sc., 1953, 12, 97. 
12. Edelman, I. S., Olney, J. M., James, A. H., Brooks, L., and Moore, F. D., Body composition: Studies in the human body by the dilution principle. Science, 1952, 115, 447.

13. Warner, G. F., Dobson, E. L., Rodgers, C. E., Johnston, M. E., and Pace, N., The measurement of total "sodium space" and total body sodium in normal individuals and in patients with cardiac edema. Circulation, 1952, 5, 915.

14. Etterich, M., Das Volumen des menschlichen Eihautsackes und seine Beziehungen zu Plazenta, Mutter und Frucht; nebst Bemerkungen ueber die Fruchtwassermenge. Gynaecologia, 1948, 126, 351.

15. Perley, A., Forbes, G. B., and Pennoyer, M. M., Determination of sodium ${ }^{2}$ "space" in infants, children and adults. J. Pediat., 1951, 38, 299.

16. Chesley, L. C., and Chesley, E. R., Extracellular water in late pregnancy and its relation to the development of toxemia. Am. J. Obst. \& Gynec., 1941, 42, 976.
17. Chesley, L. C., A study of extracellular water changes in pregnancy. Surg., Gynec. \& Obst., 1943, 76, 589.

18. Freis, E. D., and Kenny, J. F., Plasma volume, total circulating protein, and "available fluid" abnormalities in preeclampsia and eclampsia. J. Clin. Invest., 1948, 27, 283.

19. Friedman, M. M., Goodfriend, M. J., Berlin, P. F., and Goldstein, T., Extracellular fluid in normal pregnancy. Am. J. Obst. \& Gynec., 1951, 61, 609.

20. Cox, L. W., and Chalmers, T. A., The exchange of sodium between plasma and extracellular compartments in pregnant women as determined by $\mathrm{Na}^{24}$ tracer methods. J. Obst. \& Gynec. Brit. Emp., 1953, 60, 195.

21. Lambiotte-Escoffier, C., Moore, D. B., and Taylor, H. C., Jr., The volume of distribution of inulin, antipyrene, and radiosodium during normal and toxemic pregnancy and during the puerperium. Am. J. Obst. \& Gynec., 1953, 66, 18. 